Sains Malaysiana 46(1)(2017): 59-65

http://dx.doi.org/10.17576/jsm-2017-4601-08

\title{
Reliability of Panoramic-Radiograph to Determine the Position of Third-Molar from Inferior-Alveolar-Canal
}

(Kebolehpercayaan Radiograf-Panorama untuk Menentukan Posisi Molar Ketiga dari Kanal Inferior Alveolus)

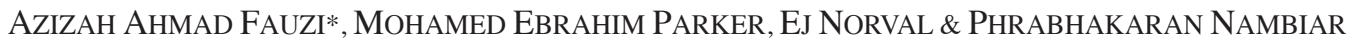

\begin{abstract}
Cone-beam-computed-tomography ( $С B C T)$ has been useful in providing insights of relevant anatomy prior to surgical procedures, including the assessment of the proximity of impacted mandibular-third-molar to the inferior-alveolar-canal (IAC). It is important to understand the reliability of conventional panoramic-radiograph in the assessment of this criterion since it is more commonly used as first line radiographic approach due to its availability and lower radiation dose. This study aimed to investigate the reliability of conventional panoramic-radiograph in the evaluation of the proximity of impacted mandibular-third-molar root tip to the IAC by correlating the results with CBCT. A total of 65 root tips of impacted mandibular-third-molars that had both panoramic radiographs and CBCT images were included in this retrospective study. Two trained observers participated in all image evaluations. A prepared standard $1 \mathrm{~cm}$ ruler was used to measure the proximity of the third-molar root apices to the IACs. Measurements recorded in this study were categorized into positive (root apex above a roof of IAC), zero (root apex was superimposed on IAC) and negative (root apex below a roof of IAC). Data analysis was carried out using student t-test. In this study, both observers recorded statistically significant differences in the measurement between third-molars root apices and the IAC from panoramic radiographs and CBCT images. The low reliability of panoramic radiograph to assess the vertical proximity between these two anatomical structures suggests the importance of additional assessment with $C B C T$ in cases where panoramic radiograph shows superimposition of the third molar root on the roof of the canal and presence of root below the roof of the IAC.
\end{abstract}

Keywords: Panoramic radiography; third molar

ABSTRAK

Sinaran-kon-tomografi-berkomputer (CBCT) amat berguna dalam memberikan kefahaman berkenaan anatomi berkaitan sebelum prosedur pembedahan, termasuklah penilaian terhadap kedudukan mandibular-molar-ketiga-terimpak ke kanal inferior alveolus (IAC). Adalah penting untuk memahami kebolehpercayaan radiograf-panorama konvensional dalam penilaian kriteria ini memandangkan ia sering digunakan sebagai pendekatan radiografi baris hadapan kerana lebih mudah diperoleh dan mempunyai dos radiasi yang rendah. Kajian ini bertujuan untuk mengenal pasti kebolehpercayaan radiograf-panorama konvensional dalam penilaian kedudukan mandibular-molar-ketiga-terimpak ke IAC dengan mengaitkan keputusannya dengan CBCT. Sebanyak 65 hujung akar mandibular-molar-ketiga-terimpak yang mempunyai kedua-dua radiograf-panorama dan imej CBCT dipilih dalam kajian retrospektif ini. Dua pemerhati terlatih terlibat dalam penilaian keseluruhan imej. Pembaris berpiawaian $1 \mathrm{~cm}$ disediakan bagi mengukur proksimiti akar molar ke IAC. Ukuran yang direkod dalam kajian ini dikategorikan kepada ukuran yang bernilai positif (akar apeks di atas bumbung IAC), sifar (akar apeks bertindih dengan IAC) dan negatif(akar apeks di bawah bumbung IAC). Analisis data dilakukan dengan menggunakan ujian-t pelajar. Dalam kajian ini, kedua-dua pemerhati merekodkan perbezaan statistik yang signifikan dalam ukuran antara apeks akar molar-ketiga dan IAC daripada radiograf-panorama serta imej СBCT. Kebolehpercayaan yang rendah bagi radiograf-panorama untuk menilai proksimiti menegak antara kedua-dua struktur anatomi ini mencadangkan kepentingan penilaian tambahan dengan CBCT dalam kes radiograf-panorama yang menunjukkan pertindihan akar pada bumbung molar-ketiga dan kehadiran akar di bawah bumbung IAC.

Kata kunci: Molar ketiga; radiograf-panorama

\section{INTRODUCTION}

Knowing the exact position of the mandibular-third-molar root apex to the IAC will help the surgeon to determine the risk of inferior-alveolar-nerve injury following surgical removal of mandibular-third-molar. This is important prior to obtain inform consent from the patient and decide the most appropriate treatment plan.
There are several radiographic approaches which have been used for preoperative assessment of the relationship between the roots of mandibular-third-molar to the IAC (Ghaeminia et al. 2009). Panoramic radiography has been used as a common diagnostic modality in dentistry, including the assessment of the impacted mandibularthird-molar. Despite being an inexpensive radiography 
procedure, this imaging modality suffers from image magnification, superimposition, ghost images and distortion (Hassan 2010).

In the presence of СBCT scanners which have been developed specifically for dental and maxillofacial imaging (Scarfe \& Farman 2008), this technology is becoming more commonly used in dentistry. The geometric and small size of the isotropic voxels of the CBCT volumetric data sets which range from 0.076 to $0.4 \mathrm{~mm}$ provides high pixel resolution with СBCT images (Scarfe \& Farman 2008).

The absence of both magnification and distortion in secondary reconstructed images from CBCT volumetric data has also been described, hence, measurements performed on this reconstruction slice can be assumed to have a one: one relationship with the actual object (Snyder 2007). Unlike panoramic radiography which uses an average dental arch as focal trough, the ability of the CBCT technology to customize the focal trough shape to suit an individual dental arch allows for improved visualization of the anatomical structures of the region of interest. It is generally agreed that СBCT proved to be a reliable technique for visualizing anatomical structures in the maxillofacial region including the IAC, and for assessing its relationship to the adjacent roots of teeth (Angelopoulus et al. 2008; Sawamura et al. 2003; Tantanapornkul et al. 2007). However, the higher radiation dose and cost of СВСТ in comparison to panoramic radiography limits the use of this modality to cases where conventional radiographic findings justify further assessment with CBCT (SEDENTEXCT project 2011). Understanding the reliability of panoramicradiograph in the assessment of third-molar to the IAC will provide better insight about the need of СВCT assessment prior to removal of impacted mandibular-third-molar.

The aim of this study was to investigate the reliability of conventional panoramic-radiograph in the evaluation of the proximity of impacted mandibular-third-molar root tip to the IAC by correlating the results obtained by means of CBCT.

\section{MATERIALS AND METHODS}

\section{SAMPLE COLLECTION}

A sample size of 65 root tips of impacted mandibular-thirdmolars that had both panoramic radiographs and $\mathrm{CBCT}$ images were included in this retrospective study. Approval from the research ethics committee, University of Western Cape and medical ethics committee, University of Malaya were obtained prior to commencement of the study.

Initially, СBCT images were selected from existing records of patients who went for СВСТ assessment prior to surgical removal of the third-molar. Then, the matching conventional panoramic images were searched from a patient records database for subsequent comparison with the $\mathrm{CBCT}$ images. Panoramic and $\mathrm{CBCT}$ machines with their operating $\mathrm{kVp}$ and $\mathrm{mA}$ that were used for radiographic acquisition in this study were described in Table 1.

The inclusion criteria employed in this study were patients older than 18 years old, the presence of fully visible impacted mandibular third molars and visible IACs. Any radiographic record which showed incomplete root formation, pathology or resorption in apical area of mandibular third molars was excluded in this study.

\section{SAMPLE PREPARATION AND DATA COLLECTION}

All the images were viewed by two trained observers in Maxillofacial Radiology. The procedures for image preparation and assessment were summarized in Figure 1.

\section{STATISTICAL ANALYSIS}

All measurements from both observers were collected and entered into a spread sheet. Means and standard deviation of the measurements recorded by both observers were calculated for each imaging modality. The reliability of panoramic radiographs in the assessment of the proximity of the root apex to the IAC was evaluated statistically by comparing panoramic radiographs measurements with CBCT image measurements using the student t-test. The student t-test was also used to evaluate the inter-observer agreement in this study.

\section{RESULTS}

In the assessment of the vertical position of 65 mandibular third molar root apices from the roof of IACs (Table 2), 44 of the cases showed negative measurement from the panoramic radiography image evaluation. This finding also showed that most of the impacted mandibular third molars showed intrusion of the root into the IAC when panoramic radiographs were assessed. The lengths of these roots within the IACs were measured to be between 0.15

TABLE 1. A list of machines used for image acquisition in this study

\begin{tabular}{ccclc}
\hline $\begin{array}{c}\text { Name of } \\
\text { machines }\end{array}$ & $\mathrm{kVp}$ & $\mathrm{mA}$ & \multicolumn{1}{c}{$\begin{array}{c}\text { Type of radiograph } \\
\text { produced }\end{array}$} & Magnification factor \\
\hline Veraview & 60 to $70 \mathrm{kVp}$ & 5 to $10 \mathrm{~mA}$ & Digital panoramic radiograph & 1.3 \\
PC-1000 & 80 to $90 \mathrm{kVp}$ & $6 \mathrm{~mA}$ & $\begin{array}{l}\text { Film based (analogue) panoramic } \\
\text { radiograph }\end{array}$ & 1.23 \\
i-CAT & $120 \mathrm{kVp}$ & $8 \mathrm{~mA}$ & CBCT images & none \\
NewTom VGi & $110 \mathrm{kVp}$ & $15 \mathrm{~mA}$ & CBCT images & none \\
\hline
\end{tabular}




\section{SAMPLES PREPARATION (PHASE 1): COMPENSATION OF IMAGE MAGNIFICATION FACTOR \& RECONSTRUCTION OF CBCT IMAGES}

- All analogue panoramic radiographs were digitized with Epson Perfection V750 Pro scanner. Thus, vertical and horizontal enlargements of $1 \mathrm{~mm}$ from the digitized radiograph were removed.

- The magnifications of horizontal and vertical components of all panoramic radiographs were also compensated by dividing these components with 1.23 or 1.3 . This depends on the panoramic machine used.

- $\quad$ All CBCT images were reconstructed into three panoramic views. The panoramic reconstruction plane which showed the closest proximity of the root apex to the IAC was selected for subsequent comparison with the matched conventional panoramic radiograph.

\section{SAMPLES PREPARATION (PHASE 2): STANDARDISATION OF IMAGES}

- $\quad$ Resized panoramic radiographs and panoramic reconstruction CBCT images were cropped and entered in Microsoft Word's spread sheets, viewed at $100 \%$.

- When image was viewed at $500 \%$, a prepared standard $1 \mathrm{~cm}$ ruler with the same magnification was positioned at an angle to the roof of the IAC (Figure 2). This was performed to achieve standardization of vertical measurement from panoramic radiographs and CBCT images.

- Further magnification of the image and the standard ruler were performed to allow better visualization of the ruler's scale and the point made on the root apex.

IMAGES MEASUREMENT \& DATA COLLECTION
- 3 categories of image measurements were recorded in this study:
- $\quad$ Positive measurement (when the root apex was measured above the roof of the IAC)
- $\quad$ Negative measurement (when the root apex was measured below the roof of the IAC)
- $\quad$ Zero measurement (when the root apex was superimposed on the IAC)
number of the patient was used as a reference of data from the same subject. A similar table was
used to record the measurements made by the second observer.

FIGURE 1. A flow chart to describe the procedures which were followed for preparation of samples (panoramic radiographs and CBCT images) as well as its assessment

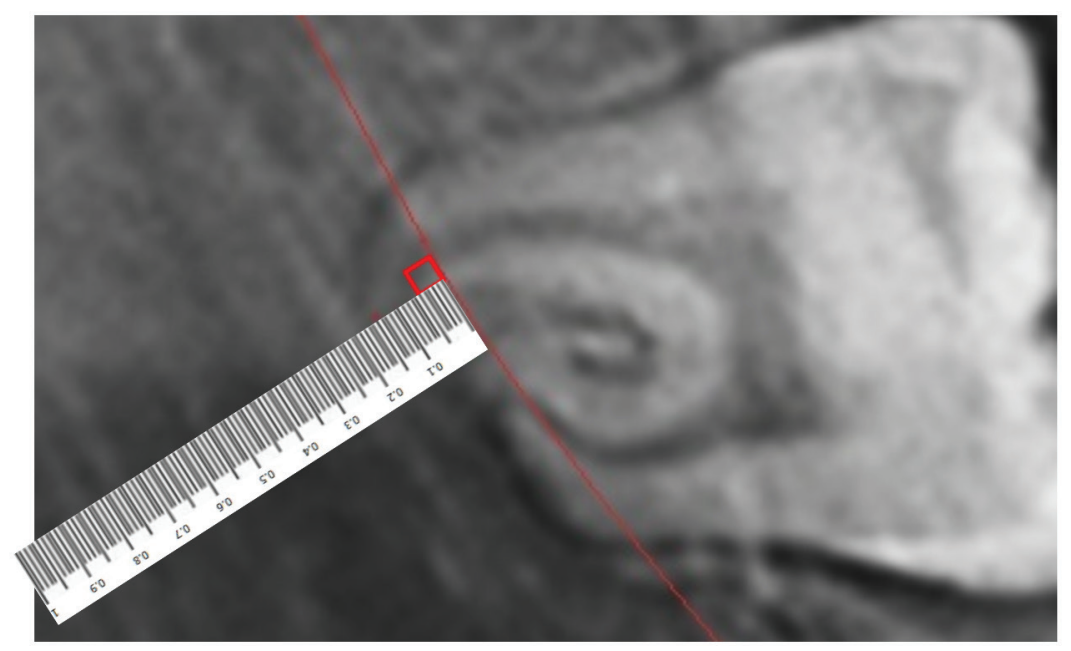

FIGURE 2. The standardize position of the magnified $1 \mathrm{~cm}$ ruler which is placed at an angle to the roof of the canal 
TABLE 2. A table of data which presents the vertical position of 65 mandibular-third-molar root apices in relation to the roof of IACs, from panoramic radiographs and CBCT images. $M$ and $m$ represent mean (SD) of maximum and minimum values measured in $\mathrm{mm}$, respectively

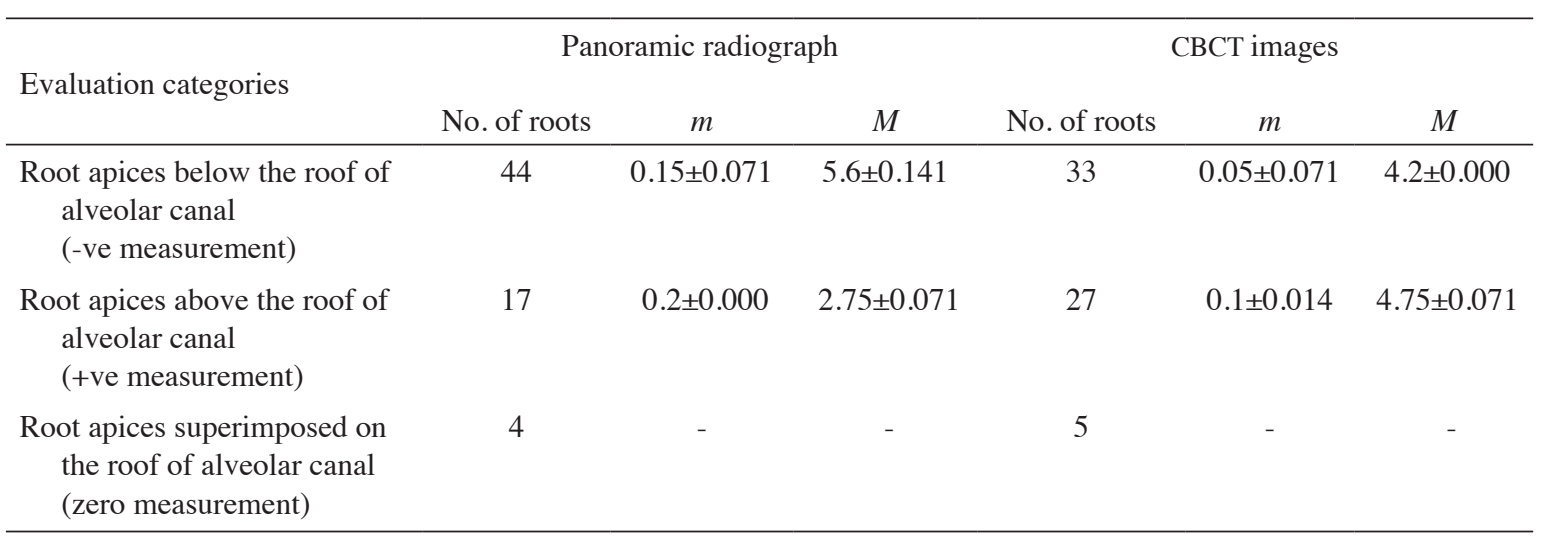

and $5.6 \mathrm{~mm}$. On СBCT, only 33 root apices were found within the alveolar canal, and the lengths ranged between 0.05 and $4.2 \mathrm{~mm}$.

On the other hand, the numbers of root apices located above the IACs which gave positive measurements in panoramic radiographs as well as CBCT images were 17 and 27 root apices, respectively. On panoramic radiographs, the thickness of bone height separating the root apices from the roof of the canal ranged from 0.2 to $2.75 \mathrm{~mm}$. Meanwhile, on CBCT images the height ranged from 0.1 to $4.75 \mathrm{~mm}$. Several superimpositions of the root apices on the roof of IACs had also been found in both imaging modalities and these were recorded as zero measurement. There were four root apices found to be superimposed on the roof of inferior alveolar canals from panoramic radiographs and five root tips on CBCT images.

An additional finding in this study indicated that eleven out of forty four roots were located within the canal from panoramic radiographs but were actually located superior to the canal on $\mathrm{CBCT}$ panoramic reconstruction slices. Two out of seventeen roots which were located less than $1 \mathrm{~mm}$ above the IAC in panoramic radiographs showed root protrusion into the canal in the СBCT images. In these two cases, we also found that the impacted molars were also associated with other special panoramic features. These additional radiographic features include interruption of lamina dura at the apex of third molar and narrowing of IAC. On both cases, CBCT images showed interruption of IAC's cortical roof with $0.1-0.5 \mathrm{~mm}$ of third molar root apices within the canal.

From this study, both observers showed significant difference between CBCT images and panoramic radiographs when measuring the vertical position between the root apices to the roof of the canals. The mean difference between panoramic radiographs and СвСТ images when measuring the vertical distance between impacted mandibular third molar root apices and the roof of the IACs, recorded by the first observer was $0.580 \mathrm{~mm}(p<0.001)$. The difference was statistically significant between the two methods. The mean difference between CBCT images and panoramic radiographs measurements made by the second observer was $0.529 \mathrm{~mm}(p<0.001)$, which also indicated a significant difference between both methods. This finding was demonstrated in the plot of СВCT image measurements against panoramic radiograph measurements (Figure 3 ). It could be seen from this plot that the red points representing CBCT image measurements were widely dispersed around the trend line of panoramic radiograph measurements, thus, indicating real bias between both methods.

In addition to this, the mean differences between the observer's measurements for both methods were also evaluated to determine the presence of bias. Using the paired version of the t-test, the mean difference in panoramic radiograph measurements between the first and the second observers was $0.047 \mathrm{~mm}$, which was small but turned out to be significantly different from zero $(p=0.020)$. At this stage, one might assume that the inter-observers agreement in the measurement of panoramic radiographs was low. However, by plotting panoramic measurements made by the first observer on the $\mathrm{X}$-axis and panoramic measurements by the second observer on the Y-axis, the points clustered closely around the straight line reflecting the presence of only small bias between the observers' measurements on panoramic radiographs (Figure 4). The significant difference in the paired version of the test was explained by comparing the numbers of negative and positive differences in these two sets of panoramic radiograph measurements. From the assessment, the proportion of the negative difference was 0.3 . This value was significantly different from 0.5 ; thus contributing to the significant difference in the paired version of the t-test, although a good inter-observers agreement was demonstrated from the plot of panoramic measurements by the first observer versus panoramic measurements by the second observer.

The mean difference in the measurements of $\mathrm{CBCT}$ images between the two observers was $0.0031 \mathrm{~mm}$ and was not significantly different from zero $(p=0.837)$. This showed the absence of bias in the СВCT measurements made by both observers. A good inter-observers agreement 


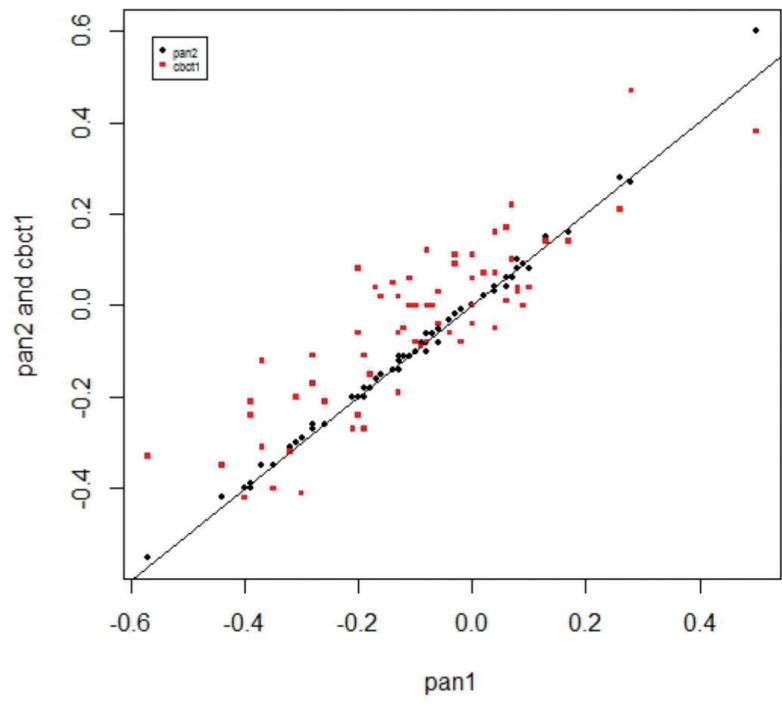

FIGURE 3. A plot of $\mathrm{X}$ and $\mathrm{Y}$ axes employed to compare CBCT image measurements by 1st observer (cbct1) versus the panoramic radiograph measurements counterpart (pan1)

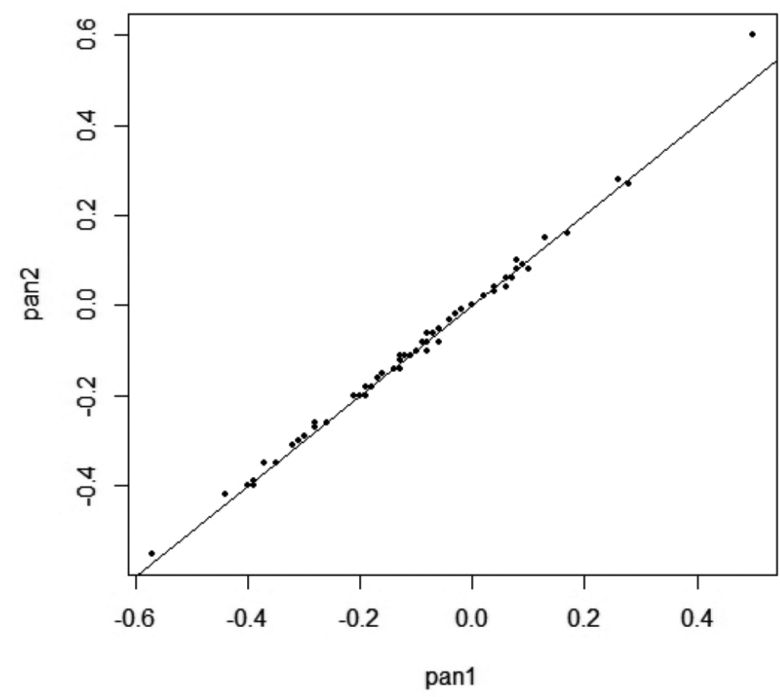

FIGURE 4. A plot of $\mathrm{X}$ and $\mathrm{Y}$ axes employed to compare measurements on panoramic radiographs by 1 st observer (pan1) versus 2nd observer (pan2)

in CBCT measurements was also demonstrated in Figure 5 , which showed a close relationship of the clustering of points around the straight line.

\section{DISCUSSION}

Understanding the limitation of conventional radiograph in the assessment of impacted third molar is paramount in determining the need of $\mathrm{CBCT}$ in selected cases and avoids unnecessary radiation exposure to the patient. Several studies have been made to compare the diagnostic accuracy of panoramic radiograph with СВCT and their findings are recorded as in Table 3 .

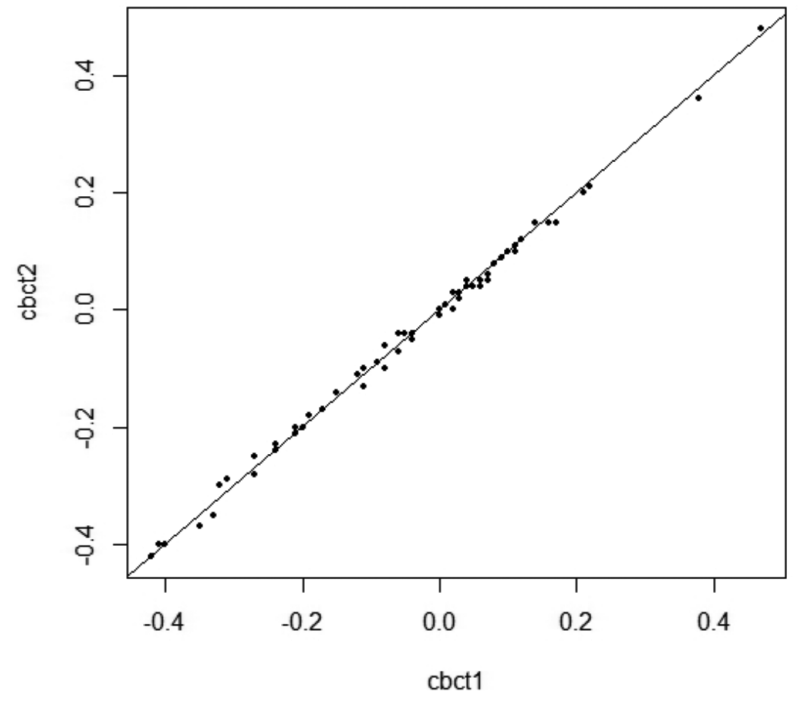

FIGURE 5. A plot of X and $\mathrm{Y}$ axes employed to compare measurements of CBCT images by 1 st observer (cbct1) versus 2 nd observer $(\operatorname{cbct} 2)$

From the literature reviews which are listed in Table 3, it can be concluded that five out of seven studies $(71.4 \%)$ suggest panoramic radiograph is less accurate than CBCT. Quantitatively, we found that CBCT proved more accurate by \pm 0.53 to $0.58 \mathrm{~mm}$ than panoramic radiograph in the measurement of the vertical position of mandibular third molar root apices to the IAC. This result is statistically significant between the two imaging modalities.

In a study of the proximity of maxillary third molars to the maxillary sinus by Hassan (2010), it had been described that superimposition of anatomical structures on conventional radiographs may result in over-projected root in the sinus. In the same manner, superimposition of buccal and lingual roots in conventional radiographs may also lead to over projection of mandibular tooth roots into the IAC.

In panoramic radiography, vertical magnification associated with this imaging modality is small and fairly constant. However, objects that are oblique which present with both vertical and horizontal components can appear slightly curved because of the significant change in the magnification of the horizontal component (Geist 2001). Since most molar roots are oblique, image distortion of this anatomical structure is likely to be present on panoramic radiographs.

In this study, although the magnification factors of panoramic radiographs were compensated before any measurements were made, the influence of the magnification factor may not be totally eliminated as the vertical and horizontal magnifications on conventional panoramic images performed by a single panoramic machine vary from one another at different rates, even when the object is placed within the focal trough. Thus, superimposition of the anatomical structures, image distortion and magnification remain the main factors which 
TABLE 3. A list of literature review which compare the diagnostic accuracy of CBCT and panoramic radiographs in the assessment of impacted mandibular third molar with IAC

\begin{tabular}{|c|c|}
\hline & Research findings \\
\hline Neugebauer et al. 2008 & $\begin{array}{l}\text { Diagnostic findings from CBCT and panoramic radiography in the assessment of the vertical } \\
\text { position of the root tip of mandibular third molars to the IAC (superior, inferior or at level of } \\
\text { the canal), presented with similar data }\end{array}$ \\
\hline Ghamenia et al. 2009 & $\begin{array}{l}\text { Panoramic image is comparable to CBCT image in predicting neurovascular bundle exposure, } \\
\text { despite its limitation to assess the horizontal relationship of the mandibular third molar root } \\
\text { apex to the IAC }\end{array}$ \\
\hline Gomes et al. 2008 & $\begin{array}{l}\text { Panoramic radiograph does not has a high diagnostic accuracy when it is used in the assessment } \\
\text { of risk in surgical extractions of lower third molars }\end{array}$ \\
\hline $\begin{array}{l}\text { Tantanapornkul et al. } 2007 \\
\text { Ghaeminia et al. } 2011\end{array}$ & $\begin{array}{l}\text { The diagnostic accuracy of } \mathrm{CBCT} \text { was superior to panoramic radiography in predicting } \\
\text { neurovascular bundle exposure following assessment of the relationship of the third molar } \\
\text { root tip to the IAC }\end{array}$ \\
\hline Hasegawa et al. 2013 & $\begin{array}{l}\text { Panoramic findings mostly inconsistent }(62.5 \%) \text { to CBCT findings. Thus, in planning surgical } \\
\text { removal of mandibular third molar, panoramic radiography alone does not provide sufficiently } \\
\text { reliable images to assess the risk associated with nerve exposure }\end{array}$ \\
\hline Peker et al. 2014 & $\begin{array}{l}\text { Less accuracy in panoramic radiograph may indicate further preoperative assessment of } \\
\text { impacted mandibular third molar with CBCT especially when darkening of the roots and } \\
\text { interruption of the white line are observed on panoramic images }\end{array}$ \\
\hline
\end{tabular}

are responsible for the inaccurate measurements of the conventional panoramic images found in the present study. The low reliability of panoramic radiographs to determine the vertical distance between the third molar root apices and the canal as demonstrated in this study suggest the importance of employing СBCT as additional diagnostic modality for better evaluation of the impacted tooth.

In this study, we also found that two out of seventeen roots which were located above the IAC on panoramic radiographs showed protrusion into the canal from the СВCT images. Whereas, eleven out of forty four roots which were located within the canal on panoramic radiographs were actually located superior to the roof of the IAC on CBCT images.

In relation to the findings, it can be concluded that eleven of forty four cases $(25 \%)$ with a high risk of nerve injury on panoramic radiographs showed alteration from the high risk to low risk after $\mathrm{CBCT}$ panoramic reconstruction slices were analyzed. On the other hand, two of seventeen cases $(11.8 \%)$ with a lower risk of nerve injury where the root apices were located above the canals changed into high risk, as СВСТ images demonstrated root protrusion into the canal. In consistent to the study by Susarla and Dodson (2007), we found that, additional preoperative evaluation of impacted mandibular third molar with CBCT can be significant in terms of determination of the risk associated with inferior alveolar nerve injury following extraction of the tooth.

As described by Hasegawa et al. (2013) and Neves et al. (2012), this study recommends additional assessment of impacted mandibular third molar with СBCT when panoramic radiographs suggest the presence of a root in the IAC or superimposition of the root on the canal.

Presences of these panoramic features are more commonly associated with the risk of IAC exposure in impacted mandibular third molar cases. In such cases, further evaluation with $\mathrm{CBCT}$ may be necessary to determine the most appropriate treatment plan such as coronectomy or extraction of the third molar. It is also important for clinician to inform the patient about the possibility of IAC exposure even though panoramic radiograph shows the root is located above the IAC. As demonstrated in this study, the presence of root above the IAC in panoramic radiograph may also associated with IAC exposure, although the risk is low. This may occur particularly in cases where there is less than $1 \mathrm{~mm}$ bone height between mandibular third molar and IAC, narrowing of canal or interruption of lamina dura at the third molar root apex.

\section{CONCLUSION}

The presence of protrusion of mandibular third molar roots in the IAC on panoramic radiographs does not always signify association of the root apices to the neurovascular bundle within the canal. In a similar fashion, the absence of root protrusion in the IAC on panoramic radiograph does not necessary indicate dissociation of the root apices from the canal on CBCT images.

The reliability of panoramic radiograph to assess the vertical proximity of the mandibular root apex to the IAC is low. It is recommended in this study to use СBCT as secondary diagnostic modality when panoramic radiograph 
shows superimposition of the third molar root on the roof of IAC and the presence of root below the roof of the canal. Additional evaluation with CBCT in such cases is important to determine the actual risk associated with the inferior alveolar nerve injury following surgical removal of impacted mandibular third molar.

\section{REFERENCES}

Angelopoulus, C., Thomas, S.L., Hechler, S., Parissis, N. \& Hlavacek, M. 2008. Comparison between digital panoramic radiography and cone-beam computed tomography for the identification of the mandibular canal as part of presurgical dental implant assessment. J. Oral Maxillofac. Surg. 66(10): 2130-2135.

Geist, J.R. 2001. Panoramic Radiography. Sullivan-Schein Dental 04AS1601. http:// www.Henryschein.com/us-en/ images/Dental/CEHP/Panoramic.pdf. Accessed on 24th January 2013.

Ghaeminia, H., Meijer, G.J., Soehardi, A., Borstlap, W.A., Mulder, J., Vlijmen, O.J., Bergé, S.J. \& Maal, T.J. 2011. The use of cone beam CT for the removal of wisdom teeth changes the surgical approach compared with panoramic radiography: A pilot study. Int. J. Oral Maxillofac. Surg. 40(8): 834-839.

Ghaeminia, H., Meijer, G.J., Soehardi, A., Borstlap, W.A., Mulder, J. \& Bergé, S.J. 2009. Position of the impacted mandibular third molar in relation to the mandibular canal. Diagnostic accuracy of cone beam computed tomography compared with panoramic radiography. Int. J. Oral Maxillofac. Surg. 38(9): 964-971.

Gomes, A.C., Vasconcelos, B.G.E., Silva, E.D., Caldas Ade, F. Jr. \& Pita Neto, I.C. 2008. Sensitivity and specificity of pantomography to predict inferior alveolar nerve damage during extraction of impacted lower third molars. J. Oral Maxillofac. Surg. 66(2): 256-259.

Hasegawa, T., Ri, S., Shigeta, T., Akashi, M., Imai, Y., Kakei, Y., Shibuya, Y. \& Komori, T. 2013. Risk factors associated with inferior alveolar nerve injury after extraction of the mandibular third molar-a comparative study of preoperative images by panoramic radiography and computed tomography. Int. J. Oral Maxillofac. Surg. 42(7): 843-851.

Hassan, B.A. 2010. Reliability of periapical radiographs and orthopantomograms in detection of tooth root protrusion in the maxillary sinus: correlation reslt with cone beam computed tomography. J. Oral Maxillofac. Res. 1(1): e6.

Neugebauer, J., Shirani, R., Mischkowski, R.A., Ritter, L., Scheer, M., Keeve, E. \& Zöller, J.E. 2008. Comparison of conebeam volumetric imaging and combined plain radiographs for localization of the mandibular canal before removal of impacted lower third molars. Oral Surg. Oral Med. Oral Pathol. Oral Radiol.Endod. 105(5): 633-642.

Neves, F.S., Souza, T.C., Almeida, S.M., Haiter-Neto, F., Freitas, D.Q. \& Bóscolo, F.N. 2012. Correlation of panoramic radiography and cone beam $\mathrm{CT}$ findings in the assessment of the relationship between impacted mandibular third molars and the mandibular canal. Dentomaxillofacial Radiology 41(7): 553-557.
Peker, I., Sarikir, C., Alkurt, M.T. \& Zor, Z.F. 2014. Panoramic radiography and cone-beam computed tomography findings in preoperative examinationof impacted mandibular third molars. BMC Oral Health 14: 71.

Sawamura, T., Minowa, K. \& Nakamura, M. 2003. Impacted teeth in the maxilla: Usefulness of 3D Dental-CT for preoperative evaluation. Eur. J. Radiol. 47(3): 221-226.

Scarfe, W.C. \& Farman, A.G. 2008. What is cone-beam CT and how does it work? Dent. Clin. North Am. 52: 707-730.

SEDENTEXCT project. 2011. Radiation Protection: Cone Beam CTfor Dental and Maxillofacial Radiology. Evidence Based Guidelines 2011. http://www.sedentexct.eu/files/ guidelines_final.pdf. Accessed on 20 March 2012.

Snyder, R.L. 2007. Cone Beam Computed Tomographic Simulation of Panoramic Radiology: Third Molar Assessment and Mandibular Canal. http://search.proquest.com/ docview $/ 304848862 /$ previewPDF? accountid $=41453$. Accessed on 15 August 2013.

Susarla, S.M. \& Dodson, T.B. 2007. Preoperative computed tomography imaging in the management of impacted mandibular third molars. J. Oral Maxillofac. Surg. 65(1): 83-88.

Tantanapornkul, W., Okouchi, K., Fujiwara, Y., Yamashiro, M., Maruoka, Y., Ohbayashi, N. \& Kurabayashi, T. 2007. A comparative study of cone-beam computed tomography and conventional panoramic radiography in assessing the topographic relationship between the mandibular canal and impacted third molars. Oral Surg. Oral Med. Oral Pathol. Oral Radiol. Endod. 103(2): 253-259.

Azizah Ahmad Fauzi

Department of Oral Biology (Clinical), Faculty of Dentistry

Universiti Kebangsaan Malaysia

Jalan Raja Muda Abd Aziz

50300 Kuala Lumpur, Federal Territory

Malaysia

Mohamed Ebrahim Parker \& EJ Norval

Department of Oral \& Maxillofacial Diagnostic Imaging

University of the Western Cape

Robert Sobukwe Road

Bellville, 7535

Republic of South Africa

Phrabhakaran Nambiar

Department of Diagnostic \& Integrated Dental Practice.

University of Malaya

50603 Kuala Lumpur, Federal Territory

Malaysia

*Corresponding author; email: azizah_fauzi@yahoo.com

Received: 26 March 2015

Accepted: 28 April 2016 